\title{
The epidemiology of nonsteroidal anti-inflammatory drugs
}

\author{
Jerry Tenenbaum MD FRCPC
}

J Tenenbaum. The epidemiology of nonsteroidal antiinflammatory drugs. Can J Gastroenterol 1999;13(2):119-122. Nonsteroidal anti-inflammatory drug (NSAID) use has increased dramatically in the past two decades. A large proportion of the elderly population (more than 65 years of age) holds a current or recent NSAID prescription, accounting for approximately $90 \%$ of all NSA ID prescriptions. Despite studies that advise finding alternatives for NSAIDs for the management of osteoarthritis, physicians often prescribe NSAIDs first for such common musculoskeletal conditions. Despite being identified as risk factors for gastrointestinal complications, the simultaneous use of two NSAIDs and the coadministration of NSAIDs with corticosteroids and with coumadin continue to occur. The point prevalence of NSAID-induced ulcers is $10 \%$ to $30 \%$, and $15 \%$ to $35 \%$ of all peptic ulcer complications are caused by NSAIDs. The increased risk of gastrointestinal complications when NSAIDs are used is $3 \%$ to $5 \%$. This risk increases with other identified risk factors (eg, older age, previous gastrointestinal history, comorbid diseases and poor health). Gastrointestinal causes of hospitalization (eg, gastrointestinal hemorrhage and perforation) and death have increased in parallel to increased NSAID use. 'Antiulcer' agents are prescribed twice as often in NSAID users, and the economic impact (eg, diagnostic tests and hospitalization) is that about one-third of the arthritis budget has been dedicated to deal with gastrointestinal side effects of NSA IDs. Misoprostol and omeprazole have been shown to be cytoprotective for the gastroduodenal mucosa when NSAIDs are used, and misoprostol has been shown to reduce the risk of gastroduodenal ulcer complications. Economic evaluations have suggested that these agents are a cost effective means of dealing with such NSAID-associated problems. Although no NSAID is totally safe, a number of studies have demonstrated that NSAIDs may be ranked according to relative gastrointestinal toxicity. The role of Helicobacter pylori in NSAID. associated problems remains uncertain.

Key Words: Cydo-oxygenase-2 specific inhibitors, Gastrointestinal toxicity, Misprostol, Nonsteroidal anti-inflammatory drugs, Omeprazole

\section{Épidémiologie des anti-inflammatoires non stéroïdiens}

RÉSUMÉ : L'emploi des anti-inflammatoires non stéroïdiens (AINS) a augmenté considérablement depu is deux décennies. Une forte proportion de la population âgée (de plus de 65 ans) a en sa possession une ordonnance récente d'AINS représentant environ $90 \%$ de toutes les ordonnances d'AINS. Malgré les études qui conseillent que l'on choisisse d'autres produits que les AINS pour le traitement de l'arthrose, les médecins les prescrivent beaucoup pour ce type de problème musculo-squelettique. Malgré le fait qu'il représente un facteur de risque de complications gastro-intestinales, l'emploi simultané de deux AINS et la coadministration des AINS avec des corticostéroïdes et le coumadin continuent de s'ob. server. La prévalence des ulcères provoqués par les AINS est de 10 à $30 \%$, et s'élève entre 15 à $35 \%$ pour toutes les complications ulcéreuses provoquées par les AINS. L'accroissement du risque de complications gastro-intestinales lorsque l'on utilise des AINS est de 3 à $5 \%$. Le risque augmente en présence d'autres facteurs de risques connus (p. ex., âge avancé, antécédents de problèmes gastro-intes. tinaux, comorbidités et piètre état de santé). Les causes gastro-intestinales de l'hospitalisation (p. ex., hémorragie digestive et perforations) et la mortalité ont augmenté parallèlement avec l'emploi croissant des AINS. Les agents anti-ulcéreux sont prescrits deux fois plus souvent chez les utilisateurs d'AINS et leur impact économique (p. ex., tests diagnostiques et hospitalisation) fait qu'environ le tiers du budget consacré à l'arthrite a servi à couvrir les dépenses associées aux effets secondaires gastro-intestinaux des AINS. Le misoprostol et l'omép razole exercent un effet cytop rotecteur sur la muqueuse gastroduodénale lorsque des AINS sont utili. sés et le misoprostol rédu it le risque d'ulcère gastroduodénal. Selon certaines études économiques, ces agents sont rentables dans la lutte contre les problèmes associés aux AINS. Bien qu'aucun AINS ne soit entièrement sécuritaire, un certain nombre d'études ont démontré que les AINS peuvent être classés selon leur toxicité gastro-intestinale relative. Le rôle d'Helicobacter pylori dans les problèmes associés aux AINS reste à confirmer.

Department of Medicine, University of Toronto; Mount Sinai Hospital, Baycrest Geriatric Centre, The Toronto Hospital, Toronto, Ontario Correspondence: DrJ Tenenbaum, Mount Sinai Hospital, 431 - 600 University Avenue, Toronto, Ontario M5G 1 X5.

Telephone 416-586-5177,fax 416-586-8434, e-mail jerry.tenenbaum@utoronto.ca 
$\mathrm{E}_{\mathrm{n}}^{\mathrm{p}}$ pidemiological studies suggest strategies for reduction of nonsteroidal anti-inflammatory drug (NSAID) toxicity, including the use of NSAIDs with proper indications, attention to dose and duration of NSAIDs, attention to risk factors, avoidance of potentially toxic drug coadministration, use of NSAIDs with less potential toxicity (including the anticipated availability of specific cyclo-oxygenase-2 [COX-2] inhibitors) and gastroduodenal mucosal cytoprotection.

NSAIDs are used for many painful conditions, including arthritis. Heat, redness and swelling of joints in arthritis are indications for the use of anti-inflammatory doses of NSAIDs.

Up until the early 1980s, there were relatively few NSAIDs available. The number has doubled in the past 15 years. NSAIDs selective for inflammatory inducible COX-2 will increase the number even more within the next three years.

Sixty-seven million prescriptions for NSAIDs were estimated to have been written in the United States in the early 1990s. Just over one-half of these were new prescriptions, which accounted for $4.5 \%$ of all written prescriptions $(1,2)$. Moreover, acetylsalicylic acid and over-the-counter NSAIDs are abundantly used in North America. A study of hospital admissions for upper gastrointestinal bleeds suggested that more patients obtained their NSAID over-the-counter than from prescriptions (3).

The elderly make up a huge proportion of individuals taking NSAIDs, accounting for perhaps one-half of all users. About $10 \%$ to $20 \%$ of these patients have a current or recent NSAID prescription. In Alberta, over a six-month study period, $27 \%$ of patients more than 65 years of age received an NSAID prescription (4-6). As well, studies confirm that NSAIDs are used by physicians for common musculoskeletal problems, including osteoarthritis. In one such study, $55 \%$ of visits to a physician for arthritis resulted in an NSAID being prescribed (7-9). Moreover, coadministration of NSAIDs with coumadin, corticosteroids or a second NSAID has been shown to be potentially dangerous in a number of family physician studies $(7,10,11)$.

Although an acute rise in NSAID use has been well documented in a recent study (1), concern about inappropriate use of NSAIDs has resulted in an altered approach to their use in Australia, with a 31\% decrease in NSAIDs prescribed (12).

Gastrointestinal symptoms and ulceration associated with NSAIDs are common. Such ulcers may bleed or perforate with life-threatening results. The point prevalence of peptic ulcers associated with NSAID use is $10 \%$ to $30 \%$ or more. This is many times what is seen in the general population $(13,14)$. About $15 \%$ to $35 \%$ of all peptic ulcer complications are caused by NSAIDs. The relative risk for peptic ulcer disease complications is increased three to five times with NSAID use (15-17). Hospitalizations have been increasing because of gastrointestinal complications of NSAID ulcers. A large number of deaths have been accounted for by these complications $(1,18)$.

Gastrointestinal ulcers associated with NSAIDs are often silent and without warning symptoms. Ulcer complications may occur early or late with NSAID use. A study of rheuma- toid arthritis patients found that such complications often occurred when patients had been on chronic NSAIDs for more than one year $(19,20)$.

Various studies confirm that peptic ulcer-related deaths occur much more often when they are associated with NSAIDs. The most common complication is hemorrhage, while perforation occurs less often $(19,20)$. In the Misoprostol Ulcer Complications Outcomes Safety Assessment (MUCOSA) study of rheumatoid arthritis patients on NSAIDs, just less than $1 \%$ of more than 8000 patients developed important complications within six months (21).

The American Rheumatism Association Medical Information System (ARAMIS) database of rheumatoid arthritis patients on NSAIDs noted a gastrointestinal hospitalization rate of $1.6 \%$, with an estimate of an approximately $0.2 \%$ mortality rate for these patients. Comparison of this rate with the expected $0.08 \%$ mortality indicates a doubling of the expected mortality rate (22). The mortality rate of rheumatoid arthritis patients on NSAIDs is the same as the cancer death rate associated with cigarettes and is greater than the death rate from cervical cancer, melanoma or asthma.

A review of multiple studies by Griffin (5) and Griffin et al (16) confirms the following risk factors for ulcer complications in those taking NSAIDs: old age; gastrointestinal history of peptic ulcer disease, hemorrhage, etc; comorbid illnesses and poor health; the dose and duration of NSAID use; and simultaneous use of certain drugs (corticosteroids, coumadin or another NSAID).

The baseline risk for peptic ulcer disease is higher in the elderly. Thus, when an elderly person takes an NSAID, the risk of complications of peptic ulcer disease is much higher (5). Some studies suggest that the risk of complications of peptic ulcers associated with NSAIDs is greatly increased to 14 to 17 times when the above risk factors are present in the patient. Overall, the complication rate is estimated at $6 \%$ to $7 \%(5,23)$. Because of these concerns, coadministration of antiulcer drugs has increased. This is especially true in the elderly. Use of these agents is twice as common in those who use NSAIDs. In one study, $28 \%$ of the use of antiulcer drugs was accounted for by NSAIDs $(6,24)$.

The economic impact of NSAID use is great. Factors contributing include coprescription of antiulcer medication, increased need for diagnostic tests, hospitalization with complications and loss of work time $(25,26)$. Thirty-one per cent of the American US $\$ 12.5$ billion budget for arthritis was used to deal with the impact of NSAIDs on the gastrointestinal tract. Gastrointestinal complications of NSAIDs result in substantial costs for the management of the arthritic patient $(24,26)$.

Many types of agents have been shown to heal gastrointestinal ulcers, including $\mathrm{H}_{2}$ receptor antagonists, the prostaglandin analogue misoprostol and proton pump inhibitors such as omeprazole $(27,28) . \mathrm{H}_{2}$ receptor antagonists, misoprostol and omeprazole may provide gastrointestinal cytoprotection against ulcer formation in the duodenum, and high dose famotidine (29), misoprostol and omeprazole may provide gastrointestinal cytoprotecion against ulcer forma- 
tion in the gastric mucosa. The MUCOSA study has shown that coadministration of misoprostol and NSAIDs to rheumatoid arthritis patients has reduced the incidence of complications of peptic ulcer disease by approximately $40 \%$ (21). Coprescribing has been suggested to be cost effective. Misoprostol has been suggested to be cost effective in reducing the risk of complications for high risk patients receiving NSAIDs. Omeprazole has been suggested to be cost effective for acute healing of gastroduodenal ulcers $(5,30,31)$.

No NSAID has been demonstrated to be absolutely safe. NSAIDs have been ranked according to their relative gastrointestinal toxicity. Differences in some cases may be dose related (ie, ibuprofen). It has been suggested that COX-2specific inhibitors are preferable because they may result in decreased toxicity $(20,32)$. Moreover, these studies suffer from certain problems, including the variety of diseases studied (eg, rheumatoid arthritis and osteoarthritis), the variation in age of patients in different studies, the variation or lack of knowledge of the health status of patients in different studies, and the variations of dose and duration of NSAIDs.

To reduce the risk of NSAID-associated gastrointestinal complications, the following guidelines are reasonable:

- An NSAID should be used only for the proper anti-inflammatory indications.

- The dose of an NSAID for a patient should be determined on an individual basis.

- The duration of NSAID use should be only what is required for the disease state being treated.

- NSAIDs with demonstrated lower risks should be selected for use when possible.

- When COX-2-specific inhibitors become available, their use should be considered, especially for those at increased risk of gastrointestinal complications.

- Coadministration of NSAIDs with coumadin, corticosteroids or a second NSAID should be avoided.

The role of Helicobacter pylori with regard to NSAIDS remains controversial.

Finally, it must be emphasized that complications of NSAID gastroduodenal disease may be lowered merely by reducing NSAID use, prescribing them only to those with arthritis in whom there is evidence of inflammation. NSAIDs should then be used only for the duration of an inflammatory event. Other choices should be considered for patients with osteoarthritis when inflammation is not present.

\section{REFERENCES}

1. Gabriel SE, Fehring RA. Trends in the utilization of non-steroidal anti-inflammatory drugs in the United States, 1986-1990. J Clin Epidemiol 1992;45:1041-4.

2. Elashoff JD, Greenfield S, Henderson D, Sturdevant AL. Physician recommendations of elective surgery for duodenal ulcer patients: a comparision of surgeons and medical specialists. Gastroenterology $1980 ; 79 \div 750-3$.

3. Wilcox CM, Shalek KA, Cotson is G. Striking prevalence of over-the-counter nonsteroidal anti-inflammatory drug use in patients with upper gastrointestinal hemorrhage. Arch Intern Med $1994 ; 154: 42-6$.

4. Gurwitz JH, Avorn J. The ambiguous relation between aging and adverse drug reactions. Ann Intern Med 1991;114:956-66.

5. Griffin MR. Epidemiology of nonsteroidal anti-inflammatory drug-associated gastrointestinal injury. Am J Med 1998;104:23S-9S.

6. Hogan DB, Campbell NR, Crutcher R, Jennett P, MacLoed N. Prescription of nonsteroidal anti-inflammatory drugs for elderly people in Alberta. Can Med Assoc J 1994;151:315-22.

7. Glazier RH, Dalby DM, Badley EM, et al. Management of common musculoskeletal problems: a survey of Ontario primary care physicians. Can Med Assoc J 1998;158:1037-40.

8. Murray MD, Brater DC. Nonsteroidal anti-inflammatory drugs. Clin Geriatr Med 1990;6:365-97.

9. Baum C, Kennedy DL, Forbes MB. Utilization of nonsteroidal antinflammatory drugs. Arthritis Rheum 1985;28:686-92.

10. Holt WS Jr, Mazzuca SA. Prescribing behaviours of family physicians in the treatment of osteoarthritis. Fam Med 1992:24:524-7.

11. Tamblyn R, McLeod PJ, Abrahamowicz M, et al. Questionable prescribing for elderly patients in Quebec. Can Med Assoc I $1994 ; 150: 1801-9$.

12. McManus P, Primrose JG, Henry DA, Birkett DJ, Lindner J, Day RO. Pattern of non-steroidal anti-inflammatory drug use in Australia 1990-1994. A report from the Drug Utilization Sub-Committee of the Pharmaceutical Benefits Advisory Committee. Med J Aust $1996 ; 164: 589-92$.

13. Hawkey CJ. Non-steroidal anti-inflammatory drugs and peptic ulcers. BMJ 1990;300:278-84.

14. Langman MJS. Epidemiological evidence on the association between peptic ulceration and antinflammatory drug use. Gastroenterology $1989 ; 96: 640-6$.

15. Lanza FL. A review of gastric ulcer and gastroduodenal injury in normal volunteers receiving aspirin and other non-steroidal anti-inflammatory drugs. Scand J Gastroenterol 1989;163:24-31.

16. Griffin MR, Piper JM, Daugherty JR, Snowden M, Ray WA. Nonsteroidal anti-inflammatory drug use and increased risk for peptic ulcer disease in elderly persons. Ann Intern Med 1991;114:257-63.

17. Gabriel SE, Jaakkimainen L, Bombardier C. Risk for serious gastrointestinal complications related to the use of nonsteroidal anti-inflammatory drugs. A meta-analysis. Ann Intern Med $1991 ; 115: 787.96$

18. Ray WA, Griffin MR, Shorr RI. Adverse drug reactions and the elderly. Health Aff (Millwood) 1990;9:114-22

19. Armstrong CP, Blower AL. Non-steroidal anti-inflammatory drugs and life threatening complications of peptic ulceration. Gut $1987 ; 28: 527-32$

20. Singh G, Ramey DR, Morfeld D, Shi H, Hatoum HT, Fries JF. Gastrointestinal tract complications of nonsteroidal anti-inflammatory drug treatment in rheumatoid arthritis. A prospective observational cohort study. Arch Intern Med $1996: 156: 1530.6$.

21. Silverstein FE, Graham DY, Senior JR, et al. Misoprostol reduces serious gastrointestinal complications in patients with rheumatoid arthritis receiving nonsteroidal anti-inflammatory drugs. A randomized, double-blind, placebo-controlled trial. Ann Intern Med 1995:123:241.9.

22. Fries J. NSAID gastropathy: the second most deadly rheumatic disease? Epidemiology and risk appraisal. J Rheumatol 1991;18:6-10.

23. Garcia Rodriguez LA, Jick H. Risk of upper gastrointestinal bleeding and perforation associated with individual non-steroidal anti-inflammatory drugs. Lancet 1994:343:769-72.

24. Smalley WE, Griffin MR, Fought RL, Ray WA. Excess costs from gastrointestinal disease associated with nonsteroidal anti-inflammatory drugs. J Gen Intern Med 1996;11:461-9.

25. Wolfe F, Kleinheksel SM, Spitz PW, et al. A multicenter study of hospitalization in rheumatoid arthritis. Frequency, medical-surgical admissions, and charges. Arthritis Rheum 1986:29:614-9.

26. Bloom BS. Direct medical costs of disease and gastrointestinal side effects during treatment for arthritis. Am J Med $1988 ; 84: 20-4$

27. Yeomans ND, Tulassay Z, Juhasz L, et al. A comparison of omeprazole with rantitidine for ulcers associated with nonsteroidal 
antiinflammatory drugs. Acid Supression Trial: Ranitidine versus Omeprazole for NSAID-associated Ulcer Treatment

(ASTRONAUT) Study Group. N Engl I Med 1998;338:719-26.

28. Hawkey CJ, Karrasch JA, Szczepanski L, et al. Omeprazole compared with misoprostol for ulcers associated with nonsteroidal antiinflammatory drugs. Omeprazole versus $\mathrm{M}$ isoprostol for NSAID-induced Ulcer Management (OMNIUM) Study Group. N Engl J Med 1998;338:727-34.

29. Taha AS, Hudson N, Hawkey CJ, et al. Famotidine for the prevention of gastric and duodenal ulcers caused by nonsteroidal antiinflammatory drugs. N Engl J Med 1996;334:1435-9.
30. Maetzel A, Ferraz MB, Bombardier C. The cost-effectiveness of misoprostol in preventing serious gastrointestinal events associated with the use of nonsteroidal antinflammatory drugs. Arthritis Rheum $1998 ; 41: 16-25$.

31. Jonsson B, Wahlqvist P. Management of nonsteroidal anti-inflammatory drug-associated lesions: a cost-effectiveness perspective. Am J Med 1998;104(3A):81S-8S.

32. Henry D, Lim LL, Garcia Rodriguez LA, et al. Variability in risk of gastrointestinal complications with individual non-steroidal anti-inflammatory drugs: results of a collaborative meta-analysis. BMJ 1996;312:1563-6. 


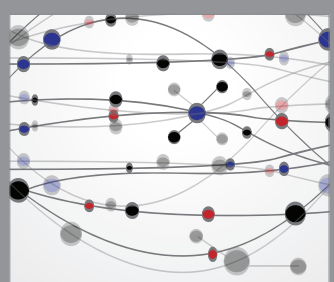

The Scientific World Journal
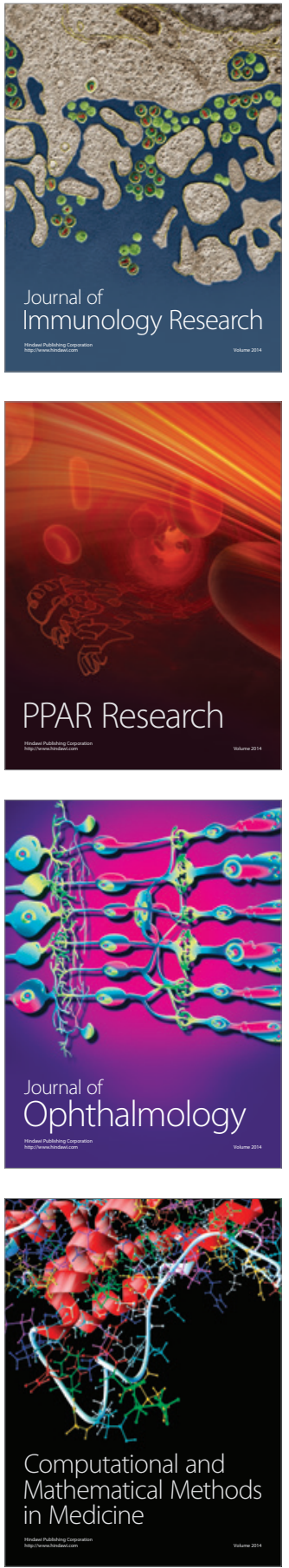

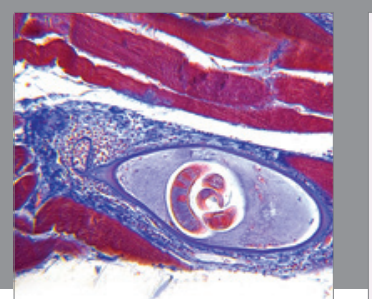

Gastroenterology Research and Practice

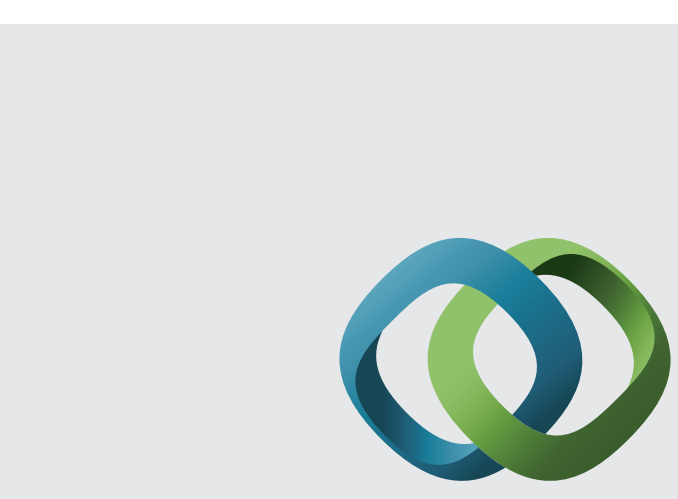

\section{Hindawi}

Submit your manuscripts at

http://www.hindawi.com
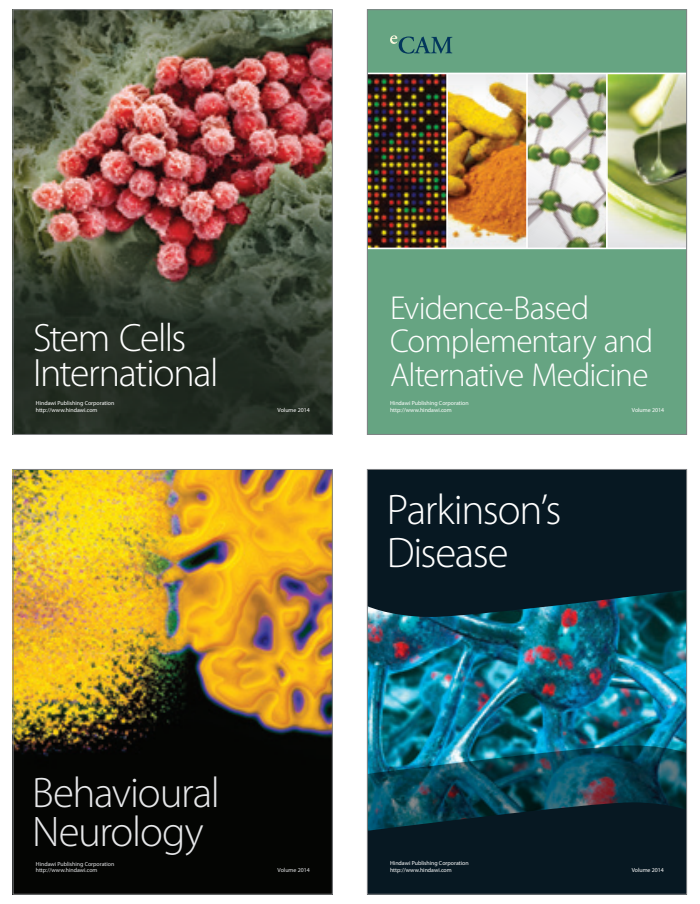
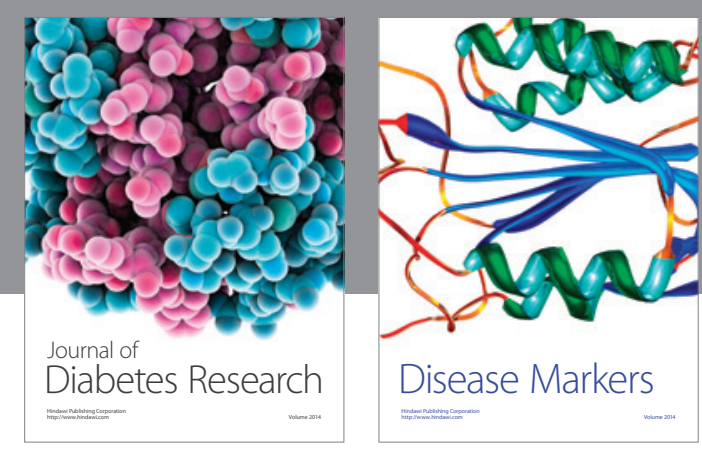

Disease Markers
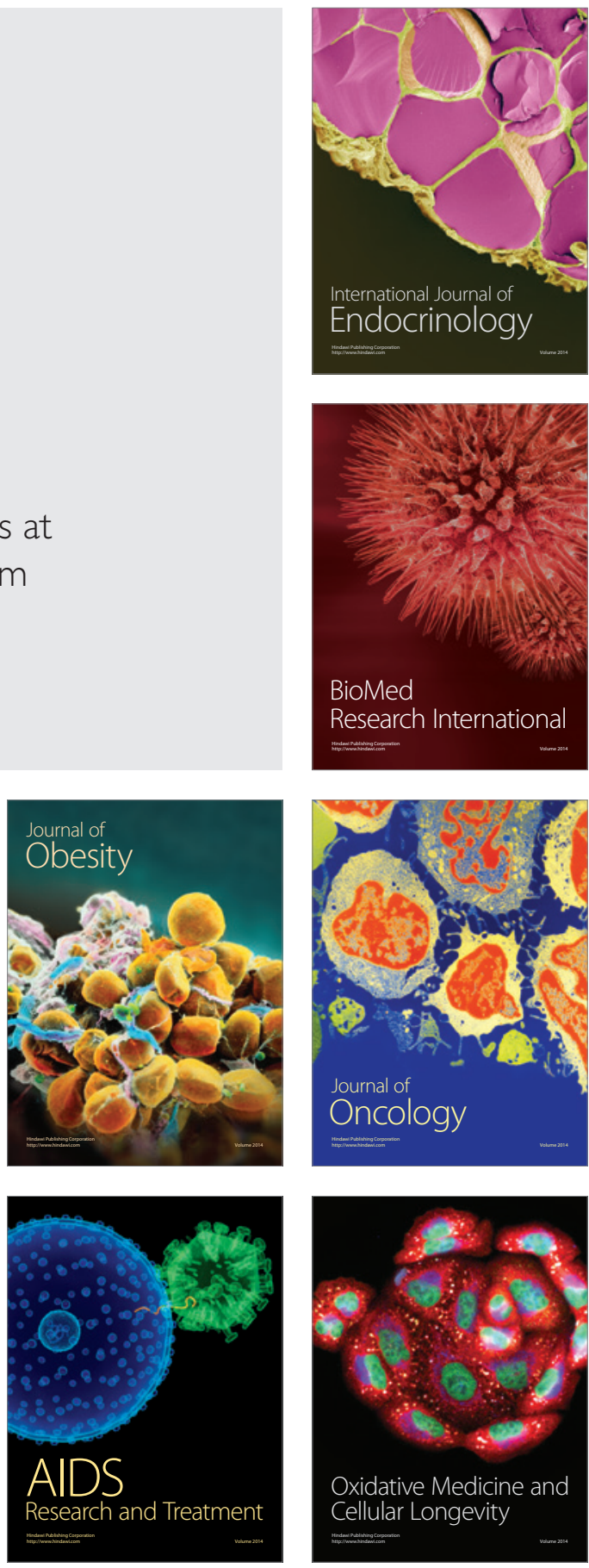